\title{
Predicting soil test phosphorus decrease in non-P-fertilized conditions
}

\author{
Stefania C. Appelhans, ${ }^{1,2,3,4}$ @ | Walter D. Carciochi ${ }^{3,4}$ | Adrian Correndo $^{4}$ | \\ Flavio H. Gutierrez Boem ${ }^{5}$ ｜ Fernando Salvagiotti ${ }^{6}$ ｜ Fernando O. Garcia ${ }^{7}$ ～ \\ Ricardo J.M. Melchiori $^{1}$ | Pedro A. Barbagelata ${ }^{1,2}$ | Luis A. Ventimiglia ${ }^{8}$ | \\ Gustavo N. Ferraris $^{9}$ | Hugo S. Vivas ${ }^{10}$ | Octavio P. Caviglia ${ }^{2,3}$ | \\ Ignacio A. Ciampitti ${ }^{4}$
}

${ }^{1}$ INTA EEA Paraná, Paraná, Argentina

${ }^{2}$ Facultad de Ciencias Agropecuarias, Universidad Nacional de Entre Ríos, Paraná, Argentina

${ }^{3}$ CONICET, Buenos Aires, Argentina

${ }^{4}$ Department of Agronomy, Kansas State University, Manhattan, Kansas

${ }^{5}$ INBA (CONICET UBA) and Soil Fertility and Fertilizers, School of Agriculture,

University of Buenos Aires, Buenos Aires, Argentina

${ }^{6}$ INTA EEA Oliveros, Santa Fe, Argentina

${ }^{7}$ International Plant Nutrition Institute,

Latin America Southern Cone, Buenos

Aires, Argentina

${ }^{8}$ INTA AER 9 de Julio, Buenos Aires, Argentina

${ }^{9}$ INTA EEA Pergamino, Buenos Aires, Argentina

${ }^{10}$ INTA EEA Rafaela, Rafaela, Argentina

\section{Correspondence}

Stefania C. Appelhans, Department of Agronomy, Kansas State University,

Manhattan, Kansas, USA.

Email: stefania_appelhans@hotmail.com Ignacio A. Ciampitti

Email: ciampitti@ksu.edu

Funding information

K-State Research and Extension (KSRE,

Grant/Award Number: 20-217-J-

\begin{abstract}
Monitoring the availability of phosphorus (P) in soil under continuous cropping facilitates finding deficiency in crops and contributes to improving crop growth and nutrient management models. Soil P availability for crops is usually estimated by soil test P (STP), such as Bray-1. This is widely used in the Americas. The relationship between the decrease of STP Bray-1 and cumulative removal of $\mathrm{P}$ was evaluated in non-P-fertilized areas in long-term studies. This removal was the sum of annual P removal over the study period as P exported in grains/crop outside the soil. The objectives were to: (a) quantify changes in STP as a function of cumulative P removal, (b) assess the relationship between relative decrease rate of STP and soil variables as well as annual removal of P by crops, and (c) develop a model to predict decrease of STP Bray-1. Exponential decay functions were used to describe annual cumulative removal of P and STP from soil over time for 12 long-term studies where no addition of P fertilizer was carried out. Changes in the relative rate of decrease of STP, relative to the initial STP Bray-1 value at the onset of the experiment, were predicted by the ratio of soil organic matter to clay and silt and the average annual $\mathrm{P}$ removal by exponential decay $\left(\mathrm{R}_{\text {adj }}^{2}=0.64\right.$; $\left.\mathrm{RMSE}=3.2 \mathrm{mg} \mathrm{kg}^{-1}\right)$. We propose this predictive model as suitable to provide estimates of the relative decrease rate of STP by Bray-1 and thereby improve management of $\mathrm{P}$ for optimizing crop yield.
\end{abstract}

\section{Highlights}

- STP Bray-1 decrease and cumulative P removal were related by exponential decay functions.

- Relative decrease rate of STP Bray-1 was related to SOM/(clay+silt) ratio and annual P removal.

- A predictive model of the relative decrease rate of STP Bray-1 was fitted and validate.

- Our model is a useful tool to help predict soil $\mathrm{P}$ availability and nutrient management. 


\section{1 | INTRODUCTION}

Crop productivity depends, among other factors, on the supply of phosphorus (P), as one of the most relevant nutrients (Raghothama, 2005). The main source of $P$ for crop production is fertilizers, mostly obtained from non-renewable phosphate rock (Cordell, Drangert, \& White, 2009). In general, $P$ fertilizers have been utilized in agriculture, and occasionally applied in excess of plant $\mathrm{P}$ requirement, resulting in both build-up of $\mathrm{P}$ in soil, loss to soil water and hence producing eutrophication of water systems (Sharpley et al., 1994). However, at a global level, $30 \%$ of the arable cropland, primarily concentrated in South America, is deficient in P (MacDonald, Bennet, Potter, \& Ramankutty, 2011). Consequently, P deficiency and the related $\mathrm{P}$ fertilizer management compromise food security, and predicting when soil available $\mathrm{P}$ becomes deficient for crops is then critical.

Long-term field studies examining continuous cropping sequences are major research investments for assessing soil nutrient cycling and balances over time (Dodd \& Mallarino, 2005; Johnston, Poulton, White, \& MacDonald, 2016; McCollum, 1991; Messiga et al., 2015; Messiga, Ziadi, Plénet, Parent, \& Morel, 2010). Such studies provide a highly valuable source of information about the effect of continual cropping sequences, $\mathrm{P}$ removal and soil fertility, especially for slowly changing variables, such as soil test P (STP). Quantification of P balances, as the difference between $\mathrm{P}$ inputs (fertilizer) and $\mathrm{P}$ outputs ( $\mathrm{P}$ removal), is a relevant topic addressed by several researchers (Johnston et al., 2016; McCollum, 1991; Messiga et al., 2010). In non-P-fertilized systems, only $\mathrm{P}$ removal by grain yield is considered to account for the $\mathrm{P}$ balance, because there are no $\mathrm{P}$ inputs as fertilizer. In non-P-fertilized fields, STP decreases due to P removal can be better predicted by using exponential decay functions than linear functions, because STP decreases less than proportional than crop P removal (Johnston et al., 2016).

Previous studies have shown that there is a relationship between decrease in STP and cumulative P removal (the sum of annual P removal across years of the considered period) in non-P-fertilized cropping sequences associated with initial STP levels (Ciampitti, Garcia, Piccone, \& Rubio, 2011a; Selles et al., 2011; Sucunza, Gutierrez Boem, Garcia, Rubio, \& Boxler, 2018; Wyngaard, Echeverria, Sainz Rozas, \& Divito, 2012). McCollum (1991) proposed two main processes driving the decrease in STP: (a) by crop $\mathrm{P}$ removal, that is, $\mathrm{P}$ exported in grains outside the system, and (b) by chemical P sorption related to P interaction with soil organic matter (SOM) and mineral particles. Therefore, the relationship between these constituents, especially with more reactive particles such as clay and silt, could be related to plant response to nutrient availability (Quiroga, Funaro, Noellemeyer, \& Peinemann, 2006). Thus, the role of SOM/(clay+silt) ratio (Pieri, 1995) in STP decrease should be further assessed, potentially reflecting the interaction from the solid soil phase and P supply from the SOM mineralization.

Although different analytical procedures are currently utilized around the globe to evaluate STP (Fixen \& Grove, 1990), Bray-1 (Bray \& Kurtz, 1945) remains one of the most commonly utilized to predict plant $\mathrm{P}$ availability in several countries in both South and North America (Beegle, 2005; Sharpley et al., 1994). The development of predictive models for changes in STP Bray- 1 as a function of cumulative $\mathrm{P}$ removal would (a) provide for more precise $\mathrm{P}$ fertilizer recommendations, (b) provide for predictions of P deficiency for crops, (c) contribute to nutrient management models for optimizing crop growth, and (d) provide forecasting of when system productivity will be compromised by a decrease in STP Bray-1.

The main goals for this study were to: (a) quantify changes in STP Bray-1 as a function of cumulative P removal, (b) assess the relationship between relative decrease rate of STP Bray-1 and soil variables as well as removal of $\mathrm{P}$ by crops on an annual basis, and (c) develop a simple model to predict the decrease of STP Bray- 1 .

\section{2 | MATERIALS AND METHODS}

\section{1 | Data search criteria}

A synthesis-analysis of data containing $\mathrm{P}$ removal and STP Bray-1 was performed with peer-reviewed published studies gathered from the scientific literature and from our own studies. Studies were obtained from Scopus, ScienceDirect, Springer, CAB Direct, Web of Science and Google Scholar. Keywords utilized in the web search engines were "phosphorus", "Bray", "yield", "soybean", "maize or corn" and "budget or balance". Studies included in the dataset met the following requirements: (a) performed under field conditions (neither glasshouse nor pot trials), (b) evaluated over at least 5 years or more of a grain cropping sequence, and (c) included grain yields, STP Bray-1 at the topsoil (0-20-cm soil depth), soil 


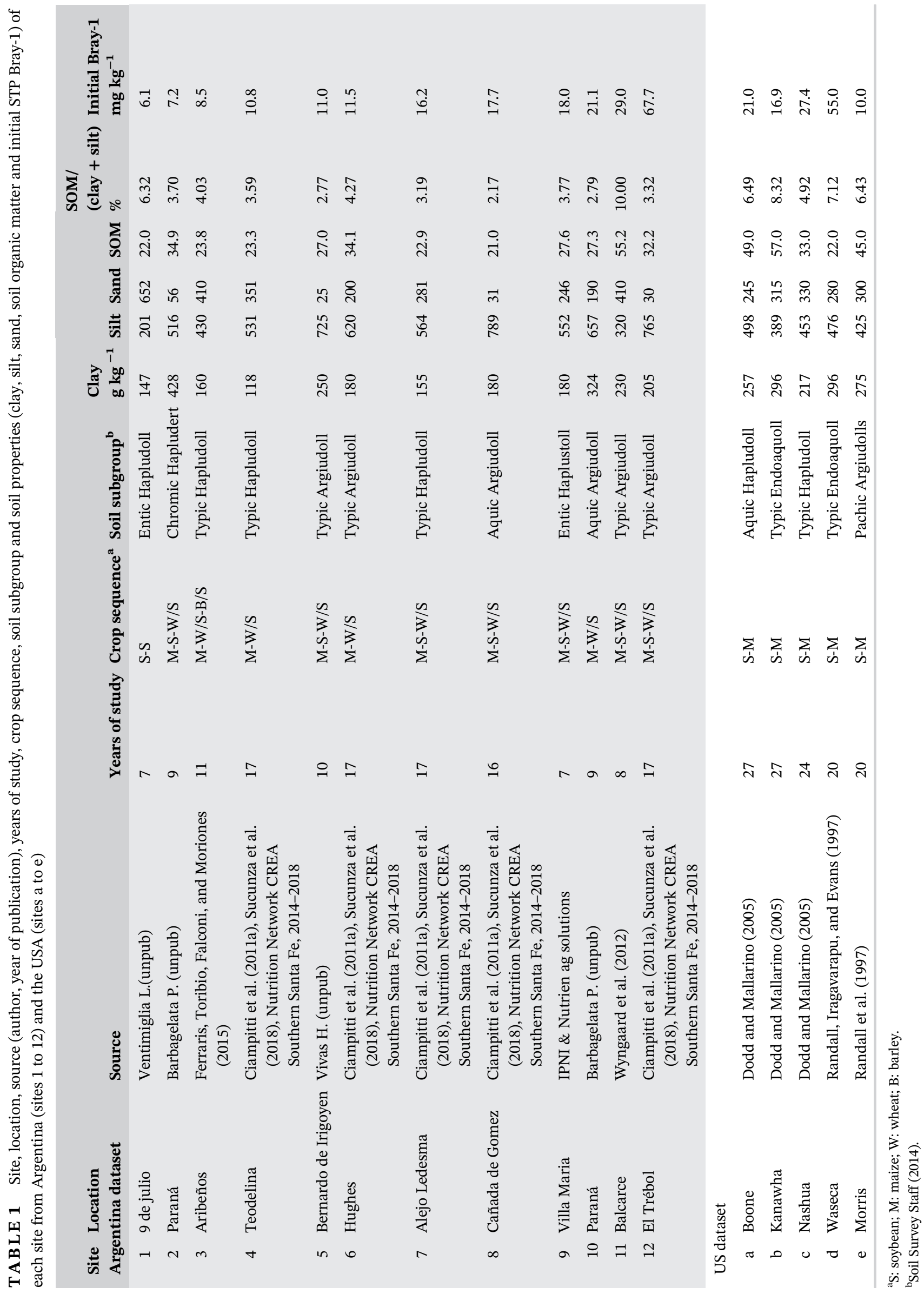


subgroup (Soil Survey Staff, 2014), top soil texture $(0-20 \mathrm{~cm}), \mathrm{SOM}$, and crop P removal $\left(\mathrm{kg} \mathrm{ha}^{-1}\right)$ and/or grain $\mathrm{P}$ concentration $\left(\mathrm{g} \mathrm{kg}^{-1}\right)$.

We used two datasets. The first one contains published and unpublished studies carried out in Argentina (Argentina dataset, Table 1, Figure 1) to consistently evaluate studies located within a restricted geographical location and fulfilling all the above-mentioned requirements. This Argentina dataset was used to build up the exponential decay model ( $n=157$ data points). For this dataset, to avoid publication bias, unpublished field studies were also collected (only those that met the standard inclusion criteria) and included as a part of the dataset. Sites 4, 6, 7, 8 and 12 were reported by Ciampitti et al. (2011a) and Sucunza et al. (2018), but four additional years were added in this study (Nutrition Network CREA Southern Santa Fe, 2014, http://research.ipni.net/project/IPNI-2000-ARG-12).

The second dataset contains studies carried out in the USA from five long-term studies ( $>20$ years) (Dodd \& Mallarino, 2005; Randall et al., 1997) (US data set, Table 1), which met the stated requirements, and it was used for model validation ( $n=100$ data points).

In both sets, data were retrieved from published text and tables and, if needed, digitized from figures using the GetData Graph Digitizer 2.26 program (Ferodov, 2013) (Table 1) (error $<1 \mathrm{mg} \mathrm{kg}^{-1}$ ). In order to avoid potential effects of $P$ fertilizer management practices (i.e., source, rate, timing and placement), only treatments without $\mathrm{P}$ addition (neither organic nor inorganic $\mathrm{P}$ sources) were considered. Information about sites, duration of study, crop sequences, soil subgroup (Soil Survey Staff, 2014), soil texture, SOM and initial STP Bray-1 are detailed in Table 1. Soils under study were mainly Mollisols and their SOM ranged from 21 to $55 \mathrm{~g} \mathrm{~kg}^{-1}$, clay from 118 to $428 \mathrm{~g} \mathrm{~kg}^{-1}$, and silt from 201 to $789 \mathrm{~g} \mathrm{~kg}^{-1}$.

The studies used for the validation were selected based on similar soil properties to those of the sites included for training the model. Thus, the validation data included Mollisols and their SOM varied from 33 to $57 \mathrm{~g} \mathrm{~kg}^{-1}$, clay from 217 to $296 \mathrm{~g} \mathrm{~kg}^{-1}$, and silt from 389 to $498 \mathrm{~g} \mathrm{~kg}^{-1}$ (Table 1). Further details related to soil features, management practices and field conditions for the model validation dataset can be found in Randall et al. (1997) and Dodd and Mallarino (2005).

\section{2 | Data analysis}

Phosphorus removal, that is, $\mathrm{P}$ exported in grains outside the system, was calculated for each year from grain $\mathrm{P}$ concentration (Sucunza et al., 2018) and grain crop yields. For studies where grain $\mathrm{P}$ concentration was not reported (sites 5 and 9), but grain crop yield was, reference grain $\mathrm{P}$ concentration data from Sucunza et al. (2018) were utilized to estimate P removal (i.e., $5.44 \mathrm{~g} \mathrm{P}$ $\mathrm{kg}^{-1}$ for soybean, $3.09 \mathrm{~g} \mathrm{P} \mathrm{kg}^{-1}$ for maize and $3.68 \mathrm{~g} \mathrm{P}$ $\mathrm{kg}^{-1}$ for wheat). For each site, average annual $\mathrm{P}$ removal was calculated as the ratio between cumulative $P$ removal (the sum of annual $\mathrm{P}$ removal across years of the considered period) and the duration of the study in years.

Clay, silt, sand and SOM content were standardized to $\mathrm{g} \mathrm{kg}^{-1}$. Soil test P Bray-1 data from 0-20-cm soil depth were utilized for the data analysis. The ratio SOM/(clay +silt) (Pieri, 1995) was calculated for each site as:

$$
\operatorname{SOM}\left(\mathrm{gkg}^{-1}\right) \times 100 /(\text { clay }+ \text { silt })\left(\mathrm{gkg}^{-1}\right) .
$$

The relationship between cumulative P removal $(x)$ and STP Bray-1(y) was fitted using an exponential decay function for each site as follows:

$$
y=y_{0} \exp (k x),
$$

where $y_{0}$ is the initial STP Bray- 1 concentration and $k$ is the relative decrease rate of STP Bray-1 decay constant. This relative decrease rate of STP Bray-1 ( $k$ parameter of equation) is relative to the initial STP Bray- 1 value at the onset of the experiment $\left(y_{0}\right)$.

Comparisons of $y_{0}$ and $k$ parameters among sites were made by testing confidence intervals of each parameter performed with GraphPad Prism 5 (Motulsky \& Christopoulos, 2003). Parameters were considered as different when confidence intervals were not overlapped.

In order to build a model to estimate the $k$ parameter, a stepwise procedure was applied to select the variables that better explain the changes in the $k$ parameter using a maximum $p$-value of .05 , by using the car package of $\mathrm{R}$ software (R Development Core Team, 2018). Tested variables were SOM, clay, silt, sand, SOM/(clay+silt) ratio, $\mathrm{SOM} /$ clay ratio, $\mathrm{pH}$, initial Bray-1, and average annual $\mathrm{P}$ removal. As a second test for model selection, we also calculated Cp Mallows, which is based on the fact that not including an important independent variable in the model results in the fitted response values being biased (Neter, Wassernan, \& Kutner, 1990). Low values $(<10)$ of Cp Mallows indicate that the model is accurate.

To validate the obtained model, $k$ was estimated from SOM, clay, silt and yield from the US dataset. Predicted and measured STP Bray-1 were tested by using the standardized major axis regression (SMA) (Warton, Wright, Falster, \& Westoby, 2006), evaluating if the slope differed from 1 and the intercept from 0 , with the smatr-3 package for R software (Warton et al., 2012). This method was chosen because it considers that predicted and measured Bray-1 present random errors, reflecting deviations in both variables. Model performance to predict STP Bray-1 was evaluated by mean square error (MSE) and root 


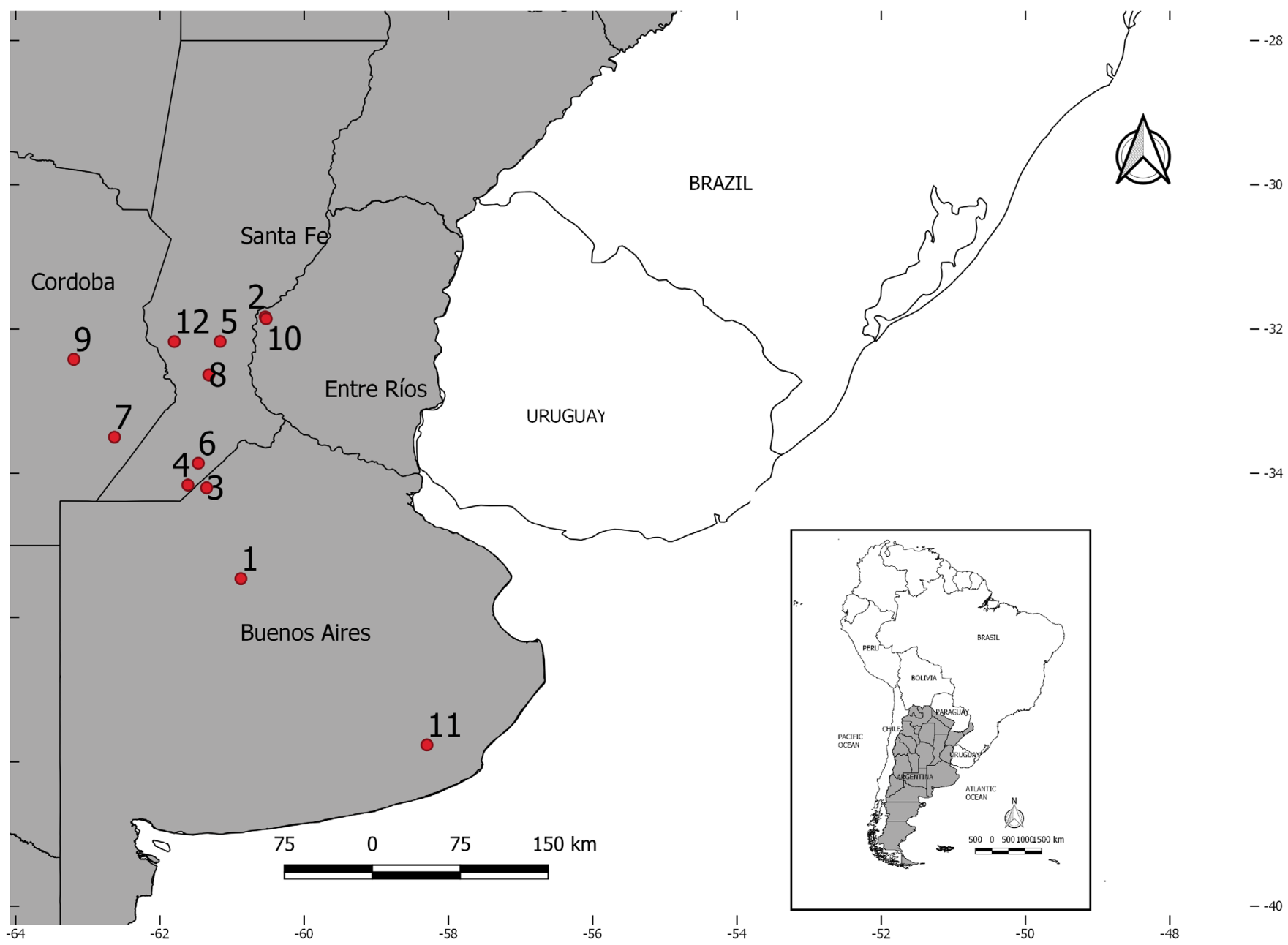

FI G U RE 1 Geographical distribution of sites under study in the pampas region of Argentina. Numbers refer to sites presented in Table 1

mean square error (RMSE) using IRENE software (Fila, Bellocchi, Acutis, \& Donatelli, 2003). The MSE was partitioned into simulation bias and mean square variation (MSV), which are orthogonal and can be analysed independently (Kobayashi \& Us Salam, 2000). The simulation bias is the bias from the observation and the mean square variation is the difference between simulated and observed bias relative to the deviation from the means.

\section{3 | RESULTS}

\section{1 | Relationship between STP Bray-1 and $P$ removal}

Annual $\mathrm{P}$ removal by crops ranged from 3.4 to $54 \mathrm{~kg} \mathrm{P} \mathrm{ha}^{-1}$ year $^{-1}$ (Figure 2). Soybean $\mathrm{P}$ removal varied from 3.4 to $49 \mathrm{~kg} \mathrm{P} \mathrm{ha}^{-1}$ year $^{-1}$, maize $\mathrm{P}$ removal from 12 to $54 \mathrm{~kg} \mathrm{P} \mathrm{ha}^{-1}$ year $^{-1}$, wheat/double-cropped soybean $\mathrm{P}$ removal from 12 to $38 \mathrm{~kg} \mathrm{P} \mathrm{ha}{ }^{-1}$ year $^{-1}$, and barley/ double-cropped soybean $\mathrm{P}$ removal ranged from 9.2 to $46 \mathrm{~kg} \mathrm{P} \mathrm{ha}^{-1}$ year $^{-1}$ (Figure 2). Initial STP Bray-1 ranged from 6.1 to $67.7 \mathrm{mg} \mathrm{P} \mathrm{kg}^{-1}$ across all evaluated sites. The variation in STP Bray-1 (initial minus final STP Bray-1) ranged from 1.9 in site 2 to $48.3 \mathrm{mg} \mathrm{kg}^{-1}$ in site 12 . At the end of each study, decrease in STP Bray-1 ranged from $26 \%$ (site 2) to $71 \%$ (site 12 ) relative to their initial value at the onset of the study.

For each site, a significant $(p<.05)$ exponential decay function between STP Bray-1 and cumulative P removal (Figure 3, Table 2) was fitted. The exponential decay analysis was split into two groups according to the duration of the studies, (a) more than 10 years and (b) less than 10 years, to portray the changes in these two groups more clearly.

\section{2 | Relative decrease rate of STP Bray-1 and predicting model}

The relative decrease rate of soil test P Bray- 1 varied from $1.17 \cdot 10^{-3}$ to $6.12 \cdot 10^{-3}$ (Table 2). Sites did not show significant differences in their $k$ parameters, but some of them differed in the " $y_{0}$ " factor, that is, the initial STP Bray-1 (Table 2). Results from the stepwise procedure showed that 
the SOM/(clay+silt) ratio and averaged annual $\mathrm{P}$ removal were the main variables explaining variations in the $k$ parameter (relative decrease rate of STP Bray-1) by a firstorder model (Table 3). Thus, the final model obtained was:

$$
\begin{gathered}
k=43.0 \cdot 10^{-4}+3.44 \cdot 10^{-4}(\mathrm{SOM} /(\text { clay }+ \text { silt })) \\
\left.-1.31 \cdot 10^{-4}(\text { average annual P removal })\right] p<.05 .
\end{gathered}
$$

The SOM/(clay+silt) ratio explained $44 \%$ of the variation in the relative decrease rate of the STP Bray-1, whereas averaged annual P removal accounted for $20 \%$ of this variation (Table 3). Other variables such as SOM, clay, silt or sand content, $\mathrm{pH}$ and initial STP Bray-1 were not significantly $(p>.05)$ related to the relative decrease rate of STP Bray-1.

\section{3 | Validation for relative decrease rate of STP Bray-1 predicting model}

The SOM/(clay+silt) ratio ranged from 4.92 to 8.32 and the average annual $\mathrm{P}$ removal from 8.7 to $21.5 \mathrm{~kg} \mathrm{P}$ $\mathrm{ha}^{-1}$ year $^{-1}$ (Table 1). Estimated values of the relative decrease rate of STP Bray-1 varied from 3.6 to $7.2 \cdot 10^{-3}$ (Figure $4 \mathrm{~b}$ ). Soil test P Bray-1 was tested by the SMA method, resulting in no differences from the 1:1 line (Figure $4 \mathrm{a}$ ). The RMSE resulted in $3.2 \mathrm{mg} \mathrm{kg}^{-1}$ with a simulation bias of $4 \%$ and a mean square variation of $96 \%$.Therefore, the model performance was adequate to predict STP Bray-1 as most of the variability in the mean square variation term was related to random error and not to bias. According to Ojeda, Volenec, Brouder, Caviglia, and Agnusdei (2017), a simulation bias below $20 \%$ indicates adequate model performance.

\section{4 | DISCUSSION}

\section{1 | STP Bray-1 and P removal}

Non-P-fertilized field studies presented curvilinear relationships for the STP Bray-1 versus P removal, with $\mathrm{P}$ equilibrium with less labile soil $P$ fractions more relevant as STP Bray-1 decreases (McCollum, 1991). When STP Bray-1 concentrations are low, $\mathrm{P}$ might be replenished from inside of soil particles that are in equilibrium with the soil solution. The decrease in labile $\mathrm{P}$, rapidly in equilibrium with soil solution, increases $\mathrm{P}$ gradient, diffusion and overall plant supply (Barrow, 1983), showing a slight decrease in STP Bray-1, although also P removal. Moreover, STP Bray-1 could be replenished from mineralization of soil organic $\mathrm{P}$, or crop residues, or recycled from deeper to upper soil layers due to the plant uptake process
(Ciampitti, Garcia, Piccone, \& Rubio, 2011b; Romaniuk et al., 2018; Zhang, MacKenzie, Liang, \& Drury, 2004).

\section{2 | Soil test $P$ Bray-1 relative decrease rate}

Some of the previous studies described the STP Bray-1 versus $\mathrm{P}$ removal relationship as linear regressions (Ciampitti et al., 2011a; Messiga et al., 2010; Selles et al., 2011) and others as exponential decay functions (Johnston et al., 2016; Sucunza et al., 2018). Owing to decrease rate of STP Bray-1 without P fertilization is reduced less than in proportion to that of $\mathrm{P}$ removal increase, exponential decay functions are more appropriate to predict the decrease of STP Bray-1, which is not constant along time (Johnston et al., 2016). Such a trend is potentially masked in short-term studies (Sucunza et al., 2018), but long-term experiments have been useful in developing and understanding this relationship (Johnston et al., 2016). Because long-term experiments are expensive and time consuming, we have proposed an innovative model that is able to predict the relative decrease rate of STP Bray-1 from simple soil properties (SOM, clay and silt content) and P removal, soil factors that can be easily measured/estimated in a relatively short time. There are no previous studies of simple (based on a few soil variables) predictive models such as the one presented in this paper, which can be utilized to estimate Bray1-P decrease, reducing the dependence on long-term, expensive and labour-intensive fertilization studies.

In general, the relationship between STP Bray-1 and cumulative P removal varies on the initial STP Bray-1, with an increase in the relative decrease rate of STP Bray-1 with increasing initial STP Bray-1 (Ciampitti et al., 2011a). In this study, initial STP Bray-1 is considered in the exponential decay function as the " $y_{0}$ " parameter, thus the relative decrease rate of STP Bray-1 was not related to initial STP Bray-1. Previous studies in soils located in the Pampas Region of Argentina have shown that initial STP Bray-1 and clay content were associated with $\mathrm{P}$ retention, and this last factor increased as soil clay content increased (Rubio, Gutiérrez Boem, \& Cabello, 2008). Moreover, clay mineralogy influences $\mathrm{P}$ retention in Mollisols related to the extractable aluminum and iron content, with greater $\mathrm{P}$ retention in soils of the southern Pampas Region as related to their parental material (Cabello, Gutierrez Boem, Quinteros, \& Rubio, 2016). Even though clay content highly influenced $\mathrm{P}$ sorption, in this study clay (as a single factor) was not related to the relative decrease rate of STP Bray-1, which is plausible because of the narrow variation range for this factor. 

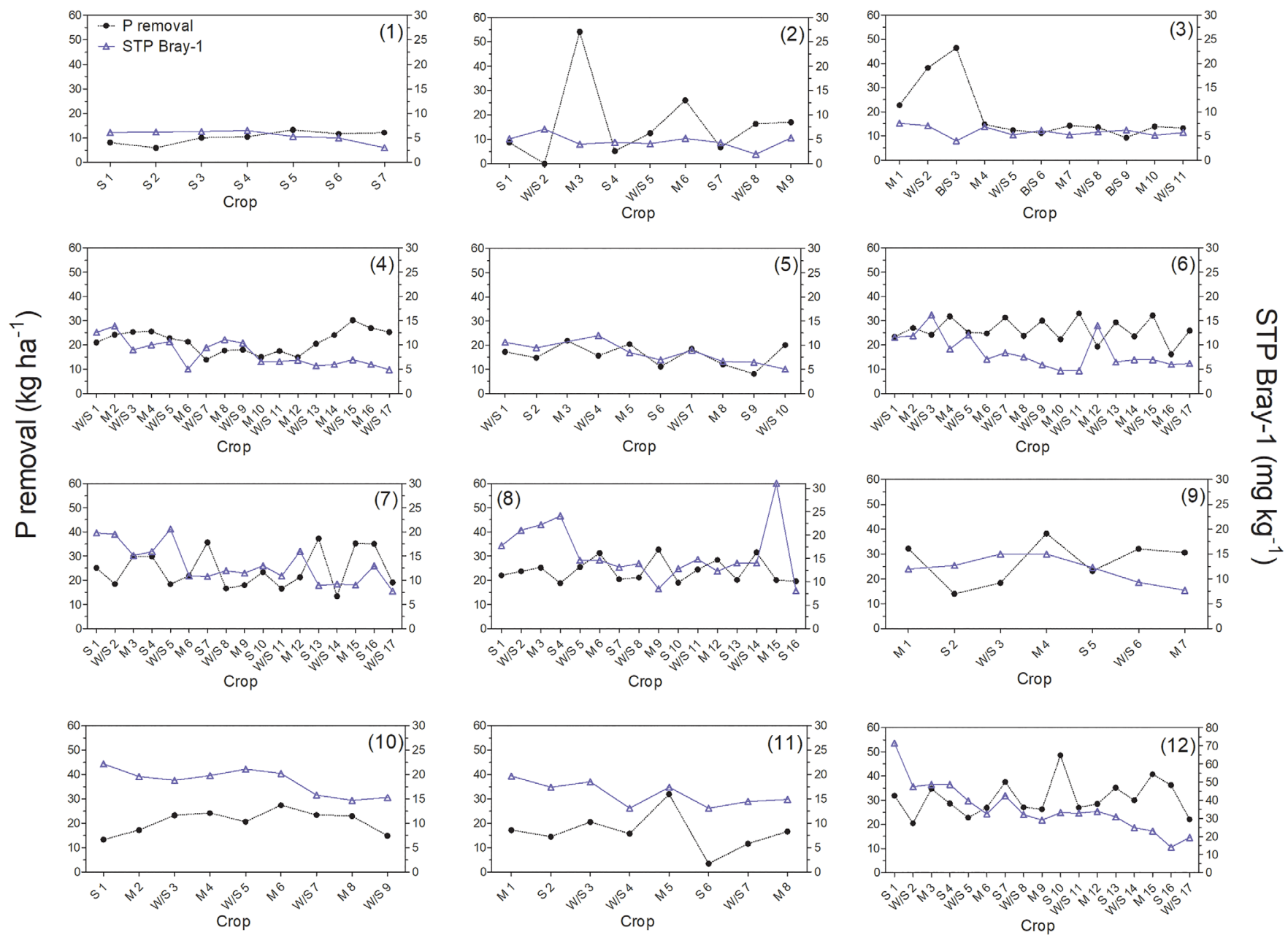

F I G U R E 2 Annual P removal and soil test phosphorus (STP) Bray-1 evolution for each year at each site of the Argentina dataset (see numbers presented in each panel and details in Table 1). M: maize; S: soybean; W/S: wheat/soybean double crop; B/S: barley/soybean double crop

F I G U RE 3 Relationship between soil test phosphorus (STP) Bray-1 and cumulative P removal during experimental years for each site of the Argentina dataset. (a) Sites with $\leq 10$ years of duration;

(b) $>10$ years of duration.

Equations and parameters for each site are shown in Table 2 (a)

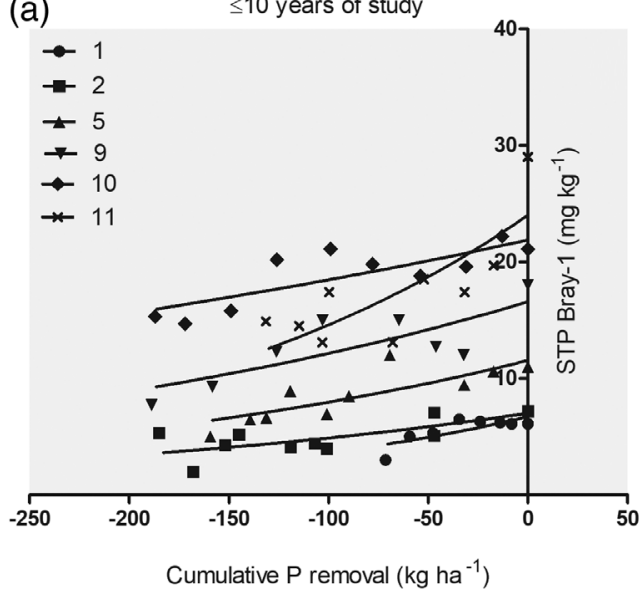

(b)

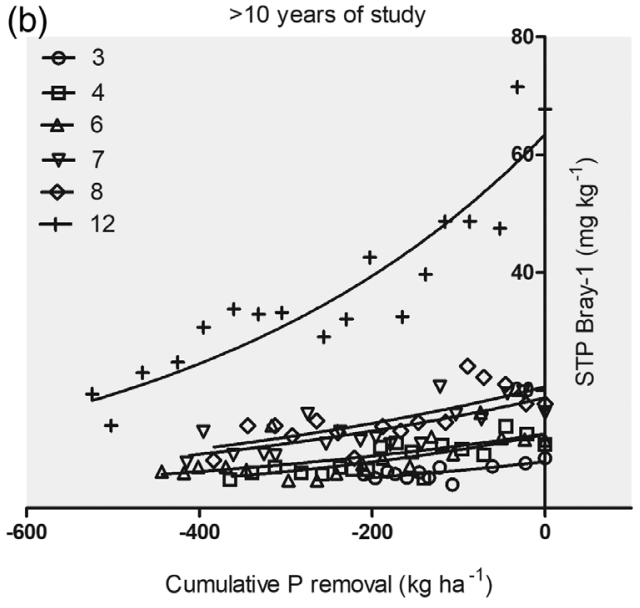

The relative decrease rate of STP Bray-1 was related to the SOM/(clay+silt) ratio and averaged annual $\mathrm{P}$ removal. In agreement with McCollum (1991), STP decrease was driven by $\mathrm{P}$ removal and a chemical decrease by $\mathrm{P}$ equilibrium with non-extractable soil $\mathrm{P}$ fractions. The $\mathrm{SOM} /($ clay+silt) ratio was proposed by Pieri (1995) as a soil structure stability index, portraying that SOM is protected by soil inorganic fine particles (clay+silt). For 
soils in Argentina, the $\mathrm{SOM} /$ (clay+silt) ratio was related to soil $\mathrm{N}$ mineralization (Quiroga et al., 2006). In addition, this ratio could be related to soil P supply from mineralization of organic P fractions, representing 29-83\% of total P in Argentinean soils (Boschetti, Quintero, Benavidez, \& Giuffre, 2003; Galantini \& Suñer, 2008; Zamuner, Picone, \& Echeverria, 2008). Phosphorus supply via organic P mineralization becomes more relevant in soils with low P concentrations (Sharpley, 1985; Stewart \& Sharpley, 1987; Thien \& Myers, 1992), but this process is not considered by STP Bray-1 determination (Appelhans, Melchiori, Barbagelata, \& Novelli, 2016; Ciampitti et al., 2011b; Suñer, Galantini, Rosell, \& Chamadoira, 2002; Wyngaard, Vidaurreta, Echeverría, \& Picone, 2013).

The relative decrease rate of STP Bray-1 increased with the $\mathrm{SOM} /($ clay+silt) ratio, potentially related to a combined effect of $\mathrm{P}$ contribution from SOM and $\mathrm{P}$ retention effects from clay plus silt soil particles. Greater $\mathrm{SOM} /($ clay + silt) ratios were recorded in soils with high

T A B LE 2 Parameters and their standard errors (SE) for the exponential decay function (Equation 2) fitted to the relationship between soil test phosphorus (STP) Bray-1 and cumulative P removal at each site

\begin{tabular}{|llll|}
\hline Site & $\boldsymbol{y}_{\boldsymbol{0}}(\mathrm{SE})\left(\mathrm{mg} \mathrm{kg}^{-\mathbf{1}}\right)$ & $\boldsymbol{k}\left(\mathbf{1 0}^{-\mathbf{3}}\right)(\boldsymbol{S} . \mathbf{E})$. & $\mathbf{R}^{\mathbf{2}}$ \\
\hline 1 & $6.7(0.5) \mathrm{e}^{*}$ & $6.12(2.25)$ & 0.59 \\
\hline 2 & $7.0(0.9) \mathrm{e}$ & $3.62(1.24)$ & 0.49 \\
\hline 3 & $7.9(0.6) \mathrm{e}$ & $2.11(0.62)$ & 0.51 \\
\hline 4 & $12.5(1.0) \mathrm{d}$ & $2.23(0.48)$ & 0.62 \\
\hline 5 & $11.6(0.9) \mathrm{d}$ & $3.72(0.98)$ & 0.65 \\
\hline 6 & $12.6(1.4) \mathrm{d}$ & $1.17(0.54)$ & 0.41 \\
\hline 7 & $18.7(1.4) \mathrm{c}$ & $1.18(0.40)$ & 0.57 \\
\hline 8 & $20.6(1.7) \mathrm{c}$ & $1.18(0.47)$ & 0.53 \\
\hline 9 & $16.6(1.5) \mathrm{bc}$ & $3.11(1.05)$ & 0.62 \\
\hline 10 & $21.9(1.0) \mathrm{b}$ & $1.69(0.45)$ & 0.39 \\
\hline 11 & $24.0(2.2) \mathrm{b}$ & $4.98(1.42)$ & 0.62 \\
\hline 12 & $63.4(3.4) \mathrm{a}$ & $2.38(0.27)$ & 0.85 \\
\hline
\end{tabular}

Note: $y_{0}$ refers to the initial STP Bray- 1 and $k$ indicates the relative decrease rate of STP Bray-1. All fitted models were significant $(p<.05)$. *Different letters between sites indicate differences among $y_{0}$ values $(p<.05)$.
SOM content (e.g., Site 11), and in soils with both low SOM and low clay content (e.g., Site 1). For the first scenario, a larger STP Bray-1 relative decrease might be a result of competition for $\mathrm{P}$ between soil solution and the SOM fraction (Blake et al., 2000), whereas in the second scenario, low clay content could be reflected as fewer soil sorption sites (greater sand composition), less P buffer capacity (Blake, Johnston, Poulton, \& Goulding, 2003) and low SOM content supplying less $\mathrm{P}$ via mineralization. Soil $\mathrm{P}$ buffer capacity is the change in the quantity of $\mathrm{P}$ sorption required per unit of change in solution $\mathrm{P}$ concentration (Moody, 2007). Thus, as P buffer capacity decreases, few labile P fractions replenish STP Bray-1, and thus, the relative decrease rate of STP Bray-1 increased, despite low $P$ removal.

Soils with similar STP Bray-1 levels but different soil texture, could differ in their P diffusion rate and P supply (Quintero, Boschetti, \& Benavidez, 2003; Silberbush \& Barber, 1983). In addition, soils with a higher relative decrease rate of STP Bray-1 showed low annual P removal. Thus, in those soils with STP Bray-1 below $15 \mathrm{mg} \mathrm{kg}^{-1}$ (average critical threshold for crops, i.e., sites 1 to 6), the annual $\mathrm{P}$ removal was low (18.9 $\left.\mathrm{kg} \mathrm{P} \mathrm{ha}^{-1}\right)$; due to this the decrease is relative to the STP Bray-1 level (average $k=3.16 \cdot 10^{-3}$ ). In contrast, sites with initial STP Bray-1 above the critical threshold showed a lower average relative decrease rate of STP Bray-1 (average $k=2.42 \cdot 10^{-3}$ ) and greater average annual $\mathrm{P}$ removal $\left(24.3 \mathrm{~kg} \mathrm{P} \mathrm{ha}^{-1}\right)$. In addition, $\mathrm{P}$ removal is affected by crop type and productivity, with crop productivity limited by $\mathrm{P}$ deficiency when STP Bray-1 is below the critical threshold (Beegle, 2005), consequently reducing $\mathrm{P}$ removal.

\section{3 | Bray-P relative decrease rate predicting model and validation}

In this sense, the validation of the STP Bray-1 decrease model with the US dataset was adequate because all studied variables for soils of the USA and the Pampas were mainly in a similar range to that explored by our model, including SOM/(clay + silt) ratio and P removal (Dodd \& Mallarino, 2005; Randall et al., 1997), with comparable SOM, clay and silt contents (Table 1). In addition,

T A B LE 3 Multiple linear regression model for relative decrease rate of STP Bray-1 $(k)$ as affected by soil and crop variables

\begin{tabular}{|c|c|c|c|c|c|c|}
\hline Variable & Regression coefficient $\cdot 10^{-4}$ & $S E \cdot 10^{-4}$ & $p$-value & Partial $\mathbf{R}^{2}$ & Adj $R^{2}$ & Cp Mallows \\
\hline $\mathrm{SOM} /($ clay+silt $)$ & 3.44 & 1.30 & .027 & 0.44 & 0.64 & 8.3 \\
\hline Averaged annual P removal & -1.31 & 0.50 & .030 & 0.20 & & 8.1 \\
\hline
\end{tabular}

Abbreviations: Adj $\mathrm{R}^{2}$ : adjusted coefficient of determination; SE: standard error. 
F I G URE 4 (a) Relationship between estimated and measured STP Bray-1 $(y=y 0$ $\exp (k x))$. (b) Predicted STP Bray1 decreases estimated by the proposed model

$\left(k=43.0 \cdot 10^{-4}+3.44 \cdot 10^{-4 *} \mathrm{SOM} /\right.$ (clay+silt) $-1.31 \cdot 10^{-4 *}$ averaged annual $\mathrm{P}$ removal) in five longterm US studies (Dodd \& Mallarino, 2005; Randall et al., 1997). RMSE: root mean square error (a)

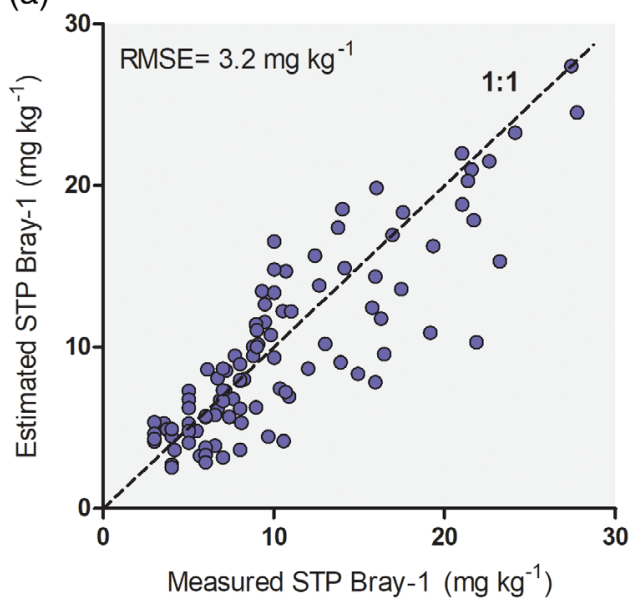

(b)

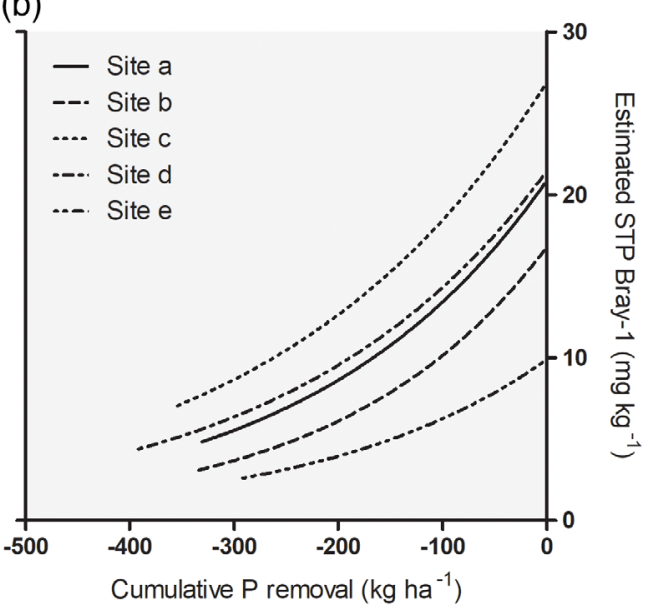

soybean and maize yields (538 to 4,308 $\mathrm{kg} \mathrm{ha}^{-1}$, and 1950 to $12,038 \mathrm{~kg} \mathrm{ha}^{-1}$, respectively) in the USA were comparable to those obtained in the Pampas. Future research should evaluate variation in soil parameters such as soil P buffer capacity (Quintero, Boschetti, \& Benavidez, 1999) to improve the prediction power of the proposed STP Bray-1 model.

Even though more data are becoming readily available, issues related to completeness of data for the main factors required to investigate changes in STP with time remain a limitation. Only a few articles were obtained studying P removal and STP Bray-1 in long-term studies under our a priori established criteria (see sub-section 2.1). During the data-searching process, although a few long-term studies with STP Bray-1 were found, yield or grain $\mathrm{P}$ concentration data, or $\mathrm{P}$ balance itself (or $\mathrm{P}$ removal), were not available in many of them. The focus on Argentina and only on STP Bray-1 (most widespread STP method used in the country; Sainz Rozas, Echeverría, \& Angelini, 2012) was also a result of a lack of consistency in the collected data (fewer studies) and different STP methods (e.g., Mehlich-3, Olsen or Colwell, among others; Beegle, 2005) used around the globe, increasing the challenges in presenting a more comprehensive and global synthesis analysis.

Long-term studies generate useful knowledge for planning management strategies for nutrient mobilization, transformation and recycling (Zicker, Von Tucher, Kavka, \& Eichler-Löbermann, 2018). These field studies present an overview of interpretation of complex processes such as changes of P with time (Dodd \& Mallarino, 2005; Messiga et al., 2010), providing useful data to build prediction models for changes in STP. The development and improvement of prediction tools for STP would require further research investments in maintaining long-term P studies and enhancing data storage and sharing to ensure the utilization of these valuable datasets in the near future.

\section{$5 \mid$ CONCLUSIONS}

The main outcomes from this study were: (a) the relative decrease rate of STP Bray-1, from the exponential decay relationship between STP Bray-1 and cumulative $\mathrm{P}$ removal, was mainly explained by the $\mathrm{SOM} /$ (clay+silt) ratio and average annual $\mathrm{P}$ removal, and (b) utilization of these variables to fit a predictive model on the relative decrease rate of STP Bray-1 was successfully implemented. The proposed model represents a relatively simple and effective approach to forecast changes in STP dynamics and to better understand the effect of $P$ removal and some soil characteristics in continuous crop sequences, mainly for Mollisols. Our finding would help in predicting and anticipating potential future crop $\mathrm{P}$ deficiencies for crops, based on improving the estimation of annual and long-term $P$ balance for farming systems. Likewise, the function may be potentially useful to include in crop growth and nutrient management simulation models. Further research should explore utilization of different soil types and cropping systems, and evaluation of multi-soil $\mathrm{P}$ tests to provide a more global STP prediction model.

\section{ACKNOWLEDGEMENTS}

Financial support was provided by K-State Research and Extension (KSRE), the Fulbright Program and the Ministry of Education and Sports of Argentina. This is contribution no. 20-217-J from the Kansas Agricultural Experiment Station. Stefania Appelhans holds a PhD scholarship and Walter Carciochi, Flavio Gutierrez Boem and Octavio P. Caviglia are members of CONICET.

\section{DATA AVAILABILITY STATEMENT}

The data that support the findings of this study are available from the corresponding author upon reasonable request. 


\section{ORCID}

Stefania C. Appelhans (1) https://orcid.org/0000-0001-

7975-5745

\section{REFERENCES}

Appelhans, S. C., Melchiori, R. J., Barbagelata, P. A., \& Novelli, L. E. (2016). Assessing organic phosphorus contributions for predicting soybean response to fertilization. Soil Science Society of America Journal, 80, 1688-1697. https://doi.org/ 10.2136/sssaj2016.04.0130

Barrow, N. J. (1983). On the reversibility of phosphate sorption by soils. Journal of Soil Science, 34, 751-758. https://doi.org/10. 1111/j.1365-2389.1983.tb01069.x

Beegle, D. (2005). Assessing soil phosphorus for crop production by soil testing. In J. T. Sims \& A. N. Sharpley (Eds.), Phosphorus: Agriculture and the environment, agronomy monograph no. 46 (pp. 123-143). Madison, WI: ASA, CSSA, SSSA.

Blake, L., Johnston, A. E., Poulton, P. R., \& Goulding, K. W. T. (2003). Changes in soil phosphorus fractions following positive and negative phosphorus balances for long periods. Plant and Soil, 254, 245-261. https://doi.org/10.1023/A: 1025544817872

Blake, L., Mercik, S., Koerschens, M., Moskal, S., Poulton, P. R., Goulding, K. W. T., ... Powlson, D. S. (2000). Phosphorus content in soil, uptake by plants and balance in three European long-term field experiments. Nutrient Cycling in Agroecosystems, 56, 263-275. https://doi.org/10.1023/A:1009841603931

Boschetti, N. G., Quintero, C. E., Benavidez, R. A., \& Giuffre, L. (2003). Cuantificación de las fracciones orgánicas e inorgánicas de fósforo en suelos de la Mesopotamia Argentina. Ciencia del Suelo, 21, 1-8.

Bray, R. H., \& Kurtz, L. T. (1945). Determination of total, organic, and available forms of phosphorus in soils. Soil Science, 59, 39-45.

Cabello, M. J., Gutierrez Boem, F., Quinteros, C., \& Rubio, G. (2016). Soil characteristics involved in phosphorus sorption in Mollisols. Soil Science Society of America Journal, 80, 1585-1590. https://doi.org/10.2136/sssaj2016.07.0235n

Ciampitti, I. A., Garcia, F. O., Piccone, L. I., \& Rubio, G. (2011a). Phosphorus budget and soil extractable dynamics in field crop rotations in Mollisols. Soil Science Society of America Journal, 75, 131-142. https://doi.org/10.2136/sssaj2009.0345

Ciampitti, I. A., Garcia, F. O., Piccone, L. I., \& Rubio, G. (2011b). Soil carbon and phosphorus pools in field crop rotations in Pampean soils of Argentina. Soil Science Society of America Journal, 75, 616-625. https://doi.org/10.2136/ sssaj2010.0168

Cordell, D., Drangert, J., \& White, S. (2009). The story of phosphorus: Global food security and food thought. Global Environmental Change, 19, 292-305. https://doi.org/10.1016/j.gloenvcha. 2008.10.009

Dodd, J. R., \& Mallarino, A. P. (2005). Soil-test phosphorus and crop grain yield responses to long-term phosphorus fertilization for corn-soybean rotations. Soil Science Society of America Journal, 69, 1118-1128. https://doi.org/10.2136/sssaj2004.0279

Ferodov, S. (2013). GetData Graph Digitizer, v2.25. Moscow, Russia. http://getdata-graph-digitizer.com.

Ferraris, G. N., Toribio, M., Falconi, R., \& Moriones, F. (2015). Efectos de diferentes estrategias de fertilización sobre los rendimientos, el balance de nutrientes y su diosponibilidad en los suelos en el largo plazo. Informaciones agronómicas de Hispanoamérica, 19, 11-17.

Fila, G., Bellocchi, G., Acutis, M., \& Donatelli, M. (2003). Irene: A software to evaluate model performance. European Journal of Agronomy, 18, 369-372. https://doi.org/10.1016/S1161-0301(02)00129-6

Fixen, P., \& Grove, J. H. (1990). Testing soils for phosphorus. In R. L. Westerman (Ed.), Soil testing and plant analysis Soil Science Society of America Book Series (3rd ed., pp. 141-180). Madison, MI: Soil Science Society of America.

Galantini, J. A., \& Suñer, L. (2008). Las fracciones orgánicas del suelo: análisis en los suelos de la Argentina. A ̌grl, 1, 41-55.

Johnston, A. E., Poulton, P. R., White, R. P., \& MacDonald, A. J. (2016). Determining the longer term decline in plant-available soil phosphorus from short-term measured values. Soil Use and Management, 32, 151-161. https://doi.org/10.1111/sum.12253

Kobayashi, K., \& Us Salam, M. (2000). Comparing simulated and measured values using mean squared deviation and its components. Agronomy Journal, 92, 345-352. https://doi.org/10.2134/ agronj2000.922345x

MacDonald, G. K., Bennet, E. M., Potter, P. A., \& Ramankutty, N. (2011). Agronomic phosphorus imbalances across the world's croplands. PNAS, 108, 3086-3091. https://doi.org/10.1073/pnas.1010808108

McCollum, R. E. (1991). Buildup and decline in soil phosphorus: 30-year trends on a Typic Umprabuult. Agronomy Journal, 83, 77-85. https://doi.org/10.2134/agronj1991.00021962008300010019x

Messiga, A. J., Ziadi, N., Jouany, C., Virkajärvi, P., Suomela, R., Sinaj, S., ... Morel, C. (2015). Soil test phosphorus and cumulative phosphorus budgets in fertilized grassland. Ambio, 44, 252-262. https://doi.org/10.1007/s13280-015-0628-X

Messiga, A. J., Ziadi, N., Plénet, D., Parent, L. E., \& Morel, C. (2010). Long-term changes in soil phosphorus status related to $\mathrm{P}$ budgets under maize monoculture and mineral $\mathrm{P}$ fertilization. Soil Use and Management, 26, 354-364. https://doi.org/10. 1111/j.1475-2743.2010.00287.x

Moody, P. W. (2007). Interpretation of a single point P buffering index for adjusting critical levels of the Colwell soil $\mathrm{P}$ test. Australian Journal of Soil Research, 45, 55-62. https://doi.org/ 10.1071/SR06056

Motulsky, H. J., \& Christopoulos, A. (2003). Fitting models to biological data using linear and nonlinear regression: A practical guide to curve fitting. San Diego: GraphPad Software. https:// www.graphpad.com/manuals/prism4/RegressionBook.pdf

Neter, J., Wassernan, W., \& Kutner, M. H. (1990). Applied linear statistical methods: Regression, analysis of variance, and experimental designs. Homewood, IL: R.D. Irwin.

Nutrition Network CREA Southern Santa Fe, 2014-2018, International Plant Nutrition Institute. http://research.ipni.net/ project/IPNI-2000-ARG-12

Ojeda, J. J., Volenec, J. J., Brouder, S. M., Caviglia, O. P., \& Agnusdei, M. G. (2017). Evaluation of agricultural production systems simulator (APSIM) as yield predictor of Panicum virgatum and Miscanthus $x$ giganteus in several US environments. GCB Bioenergy, 9, 796-816. doi.org/10.1111/gcbb.12384

Pieri, C. (1995). Long term soil management experiments in semiarid francophone Africa. In: R. Lal \& B.A. Stewart (Eds.), Soil management. Experimental basis for sustainability and environmental quality (pp. 225-266). Boca Raton, FL: CRC Press.

Quintero, C. E., Boschetti, G. N., \& Benavidez, R. A. (1999). Phosphorus retention in some soils of the Argentinean 
Mesopotamia. Communications in Soil Science and Plant Analysis, 30, 1449-1461. https://doi.org/10.1080/00103629909370299

Quintero, C. E., Boschetti, G. N., \& Benavidez, R. (2003). Effect of soil buffer capacity on soil test phosphorus interpretation and fertilizer requirement. Communications in Soil Science and Plant Analysis, 34(9-10), 1435-1450. https://doi.org/10.1081/ CSS-120020455

Quiroga, A., Funaro, D., Noellemeyer, E., \& Peinemann, N. (2006). Barley yield response to soil organic matter and texture in the pampas of Argentina. Soil and Tillage Research, 90, 63-68. https://doi.org/10.1016/j.still.2005.08.019

R Development Core Team. (2018). R: A language and environment for statistical computing. Vienna, Austria: R Foundation for Statistical Computing.

Raghothama, K. G. (2005). Phosphorus and plant nutrition: An overview. In J. T. Sims \& A. Sharpley (Eds.), Phosphorus: Agriculture and the environment (pp. 355-378). Madison, WI: American Society of Agronomy.

Randall, G. K., Iragavarapu, Z. K., \& Evans, S. D. (1997). Long-term $\mathrm{P}$ and $\mathrm{K}$ applications: I. effect on soil test incline and decline rates and critical soil test levels. Journal of Production Agriculture, 10, 565-571. https://doi.org/10.2134/jpa1997.0565

Romaniuk, R., Beltran, M., Brutti, L., Costantini, A., Bacigaluppo, S., Sainz-Rozas, H., \& Salvagiotti, F. (2018). Soil organic carbon, macro- and micronutrient changes in soil fractions with different lability in response to crop intensification. Soil and Tillage Research, 181, 136-143. https://doi.org/10. 1016/j.still.2018.04.014

Rubio, G., Gutiérrez Boem, F. H., \& Cabello, M. J. (2008). Estimating available soil phosphorus increases after phosphorus additions in Mollisols. Soil Science Society of America Journal, 72, 1721-1727. https://doi.org/10.2136/sssaj2007.0049

Sainz Rozas, H., Echeverría, H., \& Angelini, H. (2012). Fósforo disponible en suelos agrícolas de la región Pampeana y Extra Pampeana Argentina. RIA: Revista de Investigaciones Agropecuarias, 38, 33-39.

Selles, F., Campbell, C. A., Zentner, R. P., Curtin, D., James, D. C., \& Basnyat, P. (2011). Phosphorus use efficiency and long-term trends in soil available phosphorus in wheat production systems with and without nitrogen fertilizer. Canadian Journal of Soil Science, 91, 39-52. https://doi.org/10.4141/ cjss10049

Sharpley, A. N., Chapra, S. C., Wedepohl, R., Sims, J. T., Daniel, T. C., \& Reddy, K. R. (1994). Managing agricultural phosphorus for protection of surface waters: Issues and options. Journal of Environmental Quality, 23, 437-451. https://doi.org/ 10.2134/jeq1994.00472425002300030006x

Sharpley, A. N. (1985). Phosphorus cycling in unfertilized and fertilized agricultural soils. Soil Science Society of America Journal, 49, 905-911. https://doi.org/10.2136/sssaj1985. $03615995004900040023 x$

Silberbush, M., \& Barber, S. A. (1983). Sensitivity of simulated phosphorus uptake to parameters used by a mechanisticmathematical model. Plant and Soil, 74, 93-100. https://doi. org/10.1007/BF02178744

Soil Survey Staff. (2014). Soil Survey Field and Laboratory Methods Manual. Soil Survey Investigations Report 51, Version 2.0. R. Burt and Soil Survey Staff, editors, Washington, Department of Agriculture, Natural Resources Conservation Service.
Stewart, J., \& Sharpley, A. (1987). Controls on dynamics of soil and fertilizer phosphorus and sulfur. In R. Follet, J. Stewart, \& C. Cole (Eds.), Soil fertility and organic matter as critical components of production systems. SSSA Special Publication Number 19 (pp. 101-121). Madison, WI: SSSA-ASA.

Sucunza, A. F., Gutierrez Boem, F. H., Garcia, F. O., Rubio, G., \& Boxler, M. (2018). Long-term phosphorus fertilization of wheat, soybean and maize on Mollisols: Soil test trends, critical levels and balances. European Journal of Agronomy, 96, 87-95. https://doi.org/10.1016/j.eja.2018.03.004

Suñer, L. G., Galantini, J. A., Rosell, R. A., \& Chamadoira, M. D. (2002). Cambios en el contenido de las formas de fósforo en suelos de la región semiárida pampeana cultivados con trigo (Triticum aestivum L.). Revista de la Facultad de Agronomía, 104, 105-111.

Thien, S. J., \& Myers, R. (1992). Determination of bioavailable phosphorus in soil. Soil Science Society of America Journal, 56, 814-818. https://doi.org/10.2136/sssaj1992. $03615995005600030023 x$

Warton, D. I., Duursma, R. A., Falster, D. S., \& Taskinen, S. (2012). SMATR 3 - An R package for estimation and inference about allometric lines. Methods in Ecology and Evolution, 3, 257-259. htpps://doi.org/10.1111/j.2041-210X.2011.00153.x

Warton, D. I., Wright, I. J., Falster, D. S., \& Westoby, M. (2006). Bivariate line-fitting methods for allometry. Biological Reviews of the Cambridge Philosophical Society, 81, 259-291. https://doi. org/10.1017/S1464793106007007

Wyngaard, N., Vidaurreta, A., Echeverría, H. E., \& Picone, L. I. (2013). Dynamics of phosphorus and carbon in the soil particulate fraction under different management practices. Soil Science Society of America Journal, 77, 1584-1590. https://doi.org/10. 2136/sssaj2013.04.0137

Wyngaard, N., Echeverria, H. E., Sainz Rozas, H. R., \& Divito, G. A. (2012). Fertilization and tillage effects on soil properties and maize yield in a southern pampas Argiudoll. Soil and Tillage Research, 119, 22-30. https://doi.org/10.1016/j.still.2011.12.002

Zamuner, E. C., Picone, L. I., \& Echeverria, H. E. (2008). Organic and inorganic phosphorus in Mollisol soil under different tillage practices. Soil and Tillage Research, 99, 131-138. https:// doi.org/10.1016/j.still.2007.12.006

Zhang, T. Q., MacKenzie, A. F., Liang, B. C., \& Drury, C. F. (2004). Soil test phosphorus and phosphorus fractions with long-term phosphorus addition and depletion. Soil Science Society of America Journal, 68, 519-528. https://doi.org/10.2136/sssaj2004.5190

Zicker, T., Von Tucher, S., Kavka, M., \& Eichler-Löbermann, B. (2018). Soil test phosphorus as affected by phosphorus budgets in two long-term field experiments in Germany. Field Crops Research, 218, 158-170. https://doi.org/10.1016/j.fcr.2018. 01.008

How to cite this article: Appelhans SC, Carciochi WD, Correndo A, et al. Predicting soil test phosphorus decrease in non-P-fertilized conditions. Eur J Soil Sci. 2020;1-11. https://doi. org/10.1111/ejss.12946 